\title{
Continuous Surface ECG Recording for Non-human Species
}

National Cancer Institute

\section{Source}

National Cancer Institute. Continuous Surface ECG Recording for Non-human Species. NCI Thesaurus. Code C154717.

A continuous electrocardiographic (ECG) recording utilizing one or more surface leads in a non-human species. (CDISC) 